\title{
Biochar Increases Rice Yield by Improving Root Morphological and Root Physiological Functions in Heavily Saline-sodic Paddy Soil of Northeast China
}

\author{
Xiang Li, ${ }^{\text {a }}$ Tianxu Yao, ${ }^{\text {a }}$ Xiaoxuan Huang, ${ }^{\mathrm{b}}$ Xuebin Li, ${ }^{\text {a }}$ Pingyue Li, ${ }^{\text {a }}$ Shuang Du,

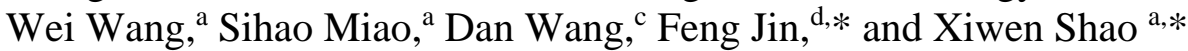

Saline-sodic soil is one of the major threats to crop growth, production, and quality. Biochar amendment could alleviate the adverse impacts of saline-sodic stress in crops. However, the effect of biochar on root morphological, root physiological functions, and rice yield in saline-sodic paddy soil has not been studied. Here, the underlying mechanisms of positive effects in morphological characteristics and physiological functions of rice roots under heavily saline-sodic paddy soil amended with biochar were evaluated. The soil was amended with biochar at zerobiochar (CK), $15 \mathrm{~g} \mathrm{~kg}^{-1}$ soil (T1), $30 \mathrm{~g} \mathrm{~kg}^{-1}$ soil (T2), or $45 \mathrm{~g} \mathrm{~kg}^{-1}$ soil (T3). Biochar addition significantly increased root length, root volume, root dry weight, and root-shoot ratio at all growth stages. The root absorption vigor and root oxidization capacity were enhanced and increased significantly by decreasing $\mathrm{Na}^{+} / \mathrm{K}^{+}$ratio, MDA content, and increasing $\mathrm{K}^{+}$concentration in rice root after biochar amendment. The root bleeding rate of biochar treatments at different growth stage were $11.01 \%$ to $67.73 \%$ greater than these of CK. The yield of rice was increased significantly under salinesodic paddy soil after biochar amendment. It was concluded that biochar had positive effect on the morphological characteristics and physiological functions in rice roots in saline-sodic paddy soil.

DOI: 10.15376/biores.17.1.1241-1256

Keywords: Biochar; Oryza sativa L.; Saline-sodic stress; Root function; Yield

Contact information: a: Agronomy College, Jilin Agricultural University, Changchun 130118, China; b: Changchun Academy of Agriculture Science, Changchun 130111, China; c: Changchun Agricultural Technology Extension Station; d: Key Laboratory of Straw Biology and Utilization, The Ministry of Education, Jilin Agricultural University, Changchun 130118, China; *Corresponding author: jinfeng@jlau.edu.cn,616530670@qq.com; Xiang Li, Tianxu Yao, and Xiaoxuan Huang contributed equally to this work.

\section{INTRODUCTION}

Soil degradation induced by salinization and/or alkalinization is a problem that adversely affects agricultural production and sustainable development (Suarez 2001). Crop growth and development are inhibited by poor physicochemical and biological properties in salt-affected soils (Qadir and Oster 2002). The Western Songnen Plain, located in northeast China $\left(42^{\circ} 30^{\prime} \mathrm{N}, 121^{\circ} 40^{\prime} \mathrm{E}\right)$, is one of the five largest saline-sodic soils in the world (Yang 2015). The growth and development of crops are affected by many direct and indirect ways under saline-sodic soil. Crop growth is restricted due to the $\mathrm{Na}^{+}$toxicity and high $\mathrm{pH}$ value in soil solution (Al-Karaki 1997; Elgharably 2011). Indirectly, crops growth may be reduced due to (i) decreased availability of water to plants caused by high osmotic 
pressure of soil solution (Munns and Tester 2008; Rengasamy 2010), (ii) decreased availability and uptake of crop nutrients due to the high $\mathrm{Na}^{+}$concentration (Qadir and Oster 2002), (iii) poor root growth caused by Na-induced deterioration of soil physical properties (Elgharably 2011), and (iv) low levels of organic carbon and poor of soil microbial activity (Shahram et al. 2018).

The physicochemical and biological characteristics of salt-affected soils have been shown to be improved by biochar (Chaganti and Crohn 2015; Ali et al. 2017; Wei et al. 2020). The role of biochar alleviating the salt-affected stress and promoting crop growth has been attributed directly through the provision of mineral nutrients for crop growth, and indirectly through lower soil bulk density (Akhtar et al. 2015; Liu et al. 2020b), improved soil stomatal density (Yang et al. 2014), and increased osmotic coefficient by enhancement of the $\mathrm{K}$ availability for higher $\mathrm{K}^{+} / \mathrm{Na}^{+}$ratio (Abrishamkesh et al. 2015; Chakraborty et al. 2016). The authors' previous research found that biochar could reduce the adverse effect of saline-sodic stress, increase dry biomass and yield, and improve quality of rice largely due to the high adsorption capacity of biochar to $\mathrm{Na}^{+}$and the cell membrane damage improvement (Ran et al. 2020; Yao et al. 2021). Farhangi-Abriz and Torabian (2017) indicated that biochar application could increase plant growth through degradation of $\mathrm{O}^{2 \cdot-}$ and $\mathrm{H}_{2} \mathrm{O}_{2}$ concentrations, antioxidant activities, and MDA content in plant cells under salted-soils. Similar findings have been reported in soybean amended with modified biochar (Mehmood et al. 2020).

Recent research has shown that biochar applications could optimize morphology and physiological characteristics, facilitate root elongation and root cell viability, enhance root absorption vigor under non-stressed soil by increasing the soil capacity to store water, and improve soil nutrient status and soil structure (Bruun et al. 2014; Xiao et al. 2016; Shahram et al. 2018; Liu et al. 2020a). Under salt-stress condition, Mehmood et al. (2020) found that the crucial role of biochar in minimizing the adverse effects of high salinity on soybean growth and efficiency of the mechanisms enabling protecting from salinity through a shift of the architecture of the root system and enhancing the antioxidant defense systems and stress-responsive genes. Shahram et al. (2018) reported similar results on mung bean.

Although many studies of biochar applications on salted soil have been reported, most studies have focused on dryland crops or on the aboveground part of crops (Chakraborty et al. 2016; Farhangi-Abriz and Torabian 2017; Liu et al. 2020a; Yao et al. 2021). To date, there are few reports on the effect of biochar on root morphological characteristics and physiological functions of rice under saline-sodic paddy soil. And the potential mechanism needs to be clarified. This study examined how the biochar application mediates a response to the saline-sodic stress in rice roots. The aims of this study were to find out whether the biochar application could improve rice yield through root morphological characteristics and physiological functions modifications under salinesodic stress, and explore the underlying mechanisms of action. It is prognosticated that the research finding will be helpful to health parameters of saline-sodic paddy field and promote the rice production in saline-sodic lands. 


\section{EXPERIMENTAL}

\section{Setup of Experiment}

A pot experiment was used to study the morphology and physiological indicators. The experiments were conducted at the Jilin Agriculture University's experimental station located in Sheli Country, Baicheng City, Jilin Province, China ( $\left.45^{\circ} 35^{\prime} \mathrm{N}, 123^{\circ} 50^{\prime} \mathrm{E}\right)$. The mean annual temperature in this experimental region is $4.7^{\circ} \mathrm{C}$. The average annual rainfall is $413.7 \mathrm{~mm}$. The average annual evaporation is $1697 \mathrm{~mm}$.

The pot experiment under open-air conditions included one hundred and ninetytwo pots (height: $40 \mathrm{~cm}$; internal diameter: $30 \mathrm{~cm}$ ), which were filled with $8.5 \mathrm{~kg}$ soil with varying amounts of biochar. Biochar was added at rates of $0 \mathrm{~g} \mathrm{~kg}^{-1}$ soil (CK), $15 \mathrm{~g} \mathrm{~kg}^{-1}$ soil (T1), $30 \mathrm{~g} \mathrm{~kg}^{-1}$ soil (T2), and $45 \mathrm{~g} \mathrm{~kg}^{-1}$ soil (T3). Each treatment was made in three replicated and laid out by completely randomized block design.

\section{Preparation of Experimental Soil}

The experimental soil samples were randomly collected at a depth of 0 to $25 \mathrm{~cm}$ for a total amount of approximately 3,000 kg from Jilin Agriculture University's experimental station. The experimental soil sieved through a $2 \mathrm{~mm}$ sieve - after air-dried. The soil was the solonchak type according to the World Reference Base for Soil Resources (IUSS Working Group 2014). The salinity, sodicity, $\mathrm{pH}$, sand, silt, clay, bulk density, and organic matter contents of experimental soils are shown in Table 1.

Table 1. Characteristics of the Analyzed Soil

\begin{tabular}{|c|c|}
\hline Soil Characteristic & Value \\
\hline Sand content (\%) & $22.13 \pm 0.97$ \\
\hline Silt content (\%) & $39.14 \pm 1.59$ \\
\hline Clay content (\%) & $35.60 \pm 1.11$ \\
\hline Bulk density $\left(\mathrm{g} \mathrm{cm}^{-3}\right)$ & $1.38 \pm 0.01$ \\
\hline $\mathrm{ECe} \mu\left(\mathrm{s} \mathrm{m}^{-1}\right)$ & $23.91 \pm 0.59$ \\
\hline $\mathrm{pH}$ & $9.64 \pm 0.06$ \\
\hline SARe $\left(\mathrm{mmolc} \mathrm{L}^{-1}\right)^{1 / 2}$ & $352.11 \pm 2.21$ \\
\hline $\mathrm{ESP}(\%)$ & $69.38 \pm 2.21$ \\
\hline Organic matter (\%) & $0.81 \pm 0.03$ \\
\hline
\end{tabular}

ECe: electrical conductivity of soil saturation extract, SAR: sodium adsorption ratio, ESP:

exchangeable sodium percentage

\section{Biochar Properties}

Biochar was made by pyrolysis of peanut shells under anoxic condition and $350{ }^{\circ} \mathrm{C}$ to $550{ }^{\circ} \mathrm{C}$ for $4 \mathrm{~h}$ in a vertical kiln. The biochar mass was ground to small pieces and then sieved through a $2 \mathrm{~mm}$ sieve. The biochar was thoroughly mixed to obtain a powdery consistency to ensure a uniform distribution in soil. The mineral contents were determined using an AAS elemental analyzer (GBC-906, GBC Science instruments Co. Ltd., Melbourne, Australia). The total content of organic carbon and nitrogen were measured using the Vario-Max Cube analyzer (Analysensysteme GmbH, Langenselbold, Germany) according to a previous study ( $\mathrm{Lu} 2000)$. The $\mathrm{pH}$ was measured with a 1:5 biochar / water suspension using the Seven Easy pH-meter and electrode comprehensive tester (S30K Mettler Toledo, Shanghai, China). The properties of raw peanut shell and biochar are presented in Table 2. 
Table 2. Properties of Raw Peanut Shell and Biochar

\begin{tabular}{|c|c|c|}
\hline \multirow{2}{*}{$\mathrm{pH}$ and Elemental Component } & \multicolumn{2}{|c|}{ Peanut Shell } \\
\cline { 2 - 3 } & Raw Material & Biochar \\
\hline $\mathrm{pH}$ & $5.56 \pm 0.11$ & $7.94 \pm 0.32$ \\
\hline $\mathrm{C}\left(\mathrm{mg} \cdot \mathrm{g}^{-1}\right)$ & $429.19 \pm 13.05$ & $540.64 \pm 26.58$ \\
\hline $\mathrm{N}\left(\mathrm{mg}^{\circ} \mathrm{g}^{-1}\right)$ & $10.85 \pm 0.61$ & $15.93 \pm 1.01$ \\
\hline $\mathrm{S}\left(\mathrm{mg} \cdot \mathrm{g}^{-1}\right)$ & $2.58 \pm 0.05$ & $6.85 \pm 0.34$ \\
\hline $\mathrm{Mg}\left(\mathrm{mg} \cdot \mathrm{g}^{-1}\right)$ & $0.29 \pm 0.00$ & $0.74 \pm 0.03$ \\
\hline $\mathrm{K}\left(\mathrm{mg} \cdot \mathrm{g}^{-1}\right)$ & $1.46 \pm 0.01$ & $0.25 \pm 0.00$ \\
\hline $\mathrm{P}\left(\mathrm{mg} \cdot \mathrm{g}^{-1}\right)$ & $5.51 \pm 0.21$ & $12.53 \pm 0.51$ \\
\hline $\mathrm{Ca}\left(\mathrm{mg} \cdot \mathrm{g}^{-1}\right)$ & $6.32 \pm 0.43$ & $2.01 \pm 0.02$ \\
\hline $\mathrm{Fe}\left(\mathrm{mg} \cdot \mathrm{g}^{-1}\right)$ & $2.77 \pm 0.09$ & $2.07 \pm 0.00$ \\
\hline $\mathrm{Be}\left(\mathrm{mg} \cdot \mathrm{g}^{-1}\right)$ & $0.14 \pm 0.00$ & $13.41 \pm 1.22$ \\
\hline $\mathrm{Mn}\left(\mathrm{mg} \cdot \mathrm{g}^{-1}\right)$ & $0.09 \pm 0.00$ & $0.06 \pm 0.00$ \\
\hline $\mathrm{Ni}\left(\mathrm{mg} \cdot \mathrm{g}^{-1}\right)$ & $0.00 \pm 0.00$ & $0.00 \pm 0.00$ \\
\hline $\mathrm{Cu}\left(\mathrm{mg} \cdot \mathrm{g}^{-1}\right)$ & $0.01 \pm 0.00$ & $0.01 \pm 0.00$ \\
\hline $\mathrm{Zn}\left(\mathrm{mg} \cdot \mathrm{g}^{-1}\right)$ & $0.02 \pm 0.00$ & $0.15 \pm 0.00$ \\
\hline $\mathrm{B}\left(\mathrm{mg} \cdot \mathrm{g}^{-1}\right)$ & $0.02 \pm 0.00$ & $0.01 \pm 0.00$ \\
\hline
\end{tabular}

C: carbon, N: nitrogen, S: Sulfur, Mg: magnesium, K: potassium, P: phosphorus, Ca: calcium, Fe: ferrum, Be: beryllium, Mn: manganese, Ni: nickel, Cu: copper, Zn: zinc, B: boron

\section{Planting Rice}

The rice variety Changbai 9 was cultivated for this experiment. The seeds were placed in tray with cattle manure compost and germinated in an unheated greenhouse. On May 22, 2018, thirty-nine days old seedlings were transplanted to each pot in the way of two hills per pot and one seedling per hill. A base fertilizer of $30 \mathrm{~g}\left(\mathrm{NH}_{4}\right)_{2} \mathrm{SO}_{4}$ per pot, 15 $\mathrm{g}$ diammonium-phosphate per pot, and $7.5 \mathrm{~g} \mathrm{~K}_{2} \mathrm{SO}_{4}$ per pot was applied before transplanting. A total of $15 \mathrm{~g}$ per pot of urea was applied at the tillering stage ( 7 days after transplanting), and $6 \mathrm{~g}$ per pot urea and $5 \mathrm{~kg} \mathrm{~K}_{2} \mathrm{SO}_{4}$ were applied at the panicle stage. The total $\mathrm{N}, \mathrm{P}$, and $\mathrm{K}$ were $5.25 \mathrm{~g}, 2.25 \mathrm{~g}$, and $1.875 \mathrm{~g}$ per pot, respectively. Biochar was broadcast on the soil surface and incorporated into the soil by plowing to depth of about $15 \mathrm{~cm} 10$ days before transplanting. Water, weeds, insects, and diseases were controlled as required to minimize yield loss.

\section{Root Physiological and Yield Measurements}

For each treatment, rice plants from 24 pots were analyzed at the following growth stages: tillering (July 13), jointing (August 1), heading (August 16), and grain-filling (September 5). Rice roots together with soil were first placed in a 40-mesh nylon sieve bag and carefully rinsed with running water. Washed roots were then gently wiped dry with filter paper. The main root length was measured by ruler. The fresh weight of root and the upper part of the plant were measured with an electronic balance (AUY220, Shimadzu, Kyoto, Japan), after which the root-shoot ratio was calculated. Root volume was measured by a drainage method (Zhang et al. 1999). The total absorption (RTA) and root active absorption area (RAA) of the root system were measured by colorimetry of methylene blue as described by Zhang et al. (1999). The root oxidation capacity (ROC) was measured based on the methods of $\alpha$-NA oxidation as described by Zhang (1992). Root bleeding rate during different rice growth was determined according to the Hirasawa et al. (1983) method at different growth stages. Rice plants were cut $5 \mathrm{~cm}$ above the soil level at 6:00 p.m. during the tillering, jointing, heading, and grain-filling stages. Each decapitated stem was firstly covered with absorbent cotton on the top and then with a polyethylene sheet. 
Moreover, paper bag was placed on the stems to prevent the stems from night dews and exposure to direct sunlight. At 8:00 a.m. of the next day, the absorbent cotton containing root sap was collected, and the root sap bleeding rate $\left(\mathrm{mg} \mathrm{h}^{-1}\right.$ plant $\left.^{-1}\right)$ was calculated according to the increase of cotton weight. The root malondialdehyde content (MDA) was quantified using the method of Stewart and Bewley (1980). The suspension was mixed and heated at $95{ }^{\circ} \mathrm{C}$ for $25 \mathrm{~min}$; the reaction was stopped by quickly placing tubes on ice. The suspension was filtered and the absorbance of the supernatant was read at 532 and $600 \mathrm{~nm}$ and MDA content was calculated using the extinction coefficient of $155 \mathrm{mM}^{-1} \mathrm{~cm}^{-1}$ and the content was expressed as nmol $\mathrm{g}^{-1} \mathrm{FW}$.

During the physiological maturity stage (September 25), the rice roots collected from three pots per treatment were rinsed with tap water and then wiped dry with filter paper. These samples were dried in an oven at $80{ }^{\circ} \mathrm{C}$ until the constant weight and ground into fine powder. The contents of $\mathrm{K}^{+}$and $\mathrm{Na}^{+}$were subsequently measured with the flame photometer (M410, Sherwood Ltd, Cambridge, UK) after nitric-perchloric acid (1\%) digestion (Bastías et al. 2004). At maturity, rice plants of each treatment from five pots were harvested by cutting at the soil level to determine the rice yield. Numbers of panicles per hill (NPP), number of spikelets per panicle (SP), Seed setting rate (SSR), 1,000-grain weight $(\mathrm{GW})$ and grain yield per hill (YP) were recorded.

\section{Statistical Analysis}

Descriptive statistics were used to the test the mean and standard deviation of the measured parameters. The effects of biochar on the measured parameters were evaluated using one-way ANOVA (analysis of variance). Significant differences among means were detected using the least significant difference (LSD) test at $\mathrm{p}<0.05$. The SPSS 18.0 software (IBM, Inc. Chicago, IL, USA) was used for all statistical analysis.

\section{RESULTS AND DISCUSSION}

\section{Root Morphological Characteristics}

Biochar application positively affected the rice root morphological characteristics under saline-sodic paddy soil (Table 3 ). The main root length, root volumes and root dry weight were significantly increased by adding biochar at all analyzed growth stages, and the values kept rising with increasing of biochar application. There were significant differences $(\mathrm{P}<0.05)$ between biochar treatment and $\mathrm{CK}$ during the tillering, jointing, heading, and filling stages. Thus, applying biochar to the saline-sodic paddy soil could significantly improve root morphological index, promote root growth, and increase nutrient uptake of rice. 
Table 3. Effects of Biochar on Rice Root Morphology in Different Growth Stages

\begin{tabular}{|c|c|c|c|c|c|}
\hline Trait & Treatment & Tillering stage & Jointing stage & Heading stage & Filling stage \\
\hline \multirow{4}{*}{$\begin{array}{l}\text { Main root } \\
\text { length }(\mathrm{cm})\end{array}$} & CK & $10.95 \pm 0.17 c$ & $14.50 \pm 0.27 b$ & $16.33 \pm 0.13 c$ & $16.70 \pm 0.27 b$ \\
\hline & T1 & $14.50 \pm 0.16 b$ & $16.10 \pm 0.19 a$ & $17.85 \pm 0.12 b$ & $17.75 \pm 0.05 a$ \\
\hline & T2 & $14.75 \pm 0.12 b$ & $16.35 \pm 0.11 \mathrm{a}$ & $20.65 \pm 0.31 a$ & $17.25 \pm 0.16 a$ \\
\hline & T3 & $16.35 \pm 0.24 a$ & $18.50 \pm 0.19 a$ & $21.55 \pm 0.43 a$ & $18.35 \pm 0.39 a$ \\
\hline \multirow{4}{*}{$\begin{array}{l}\text { Root volume } \\
\qquad\left(\mathrm{cm}^{3}\right)\end{array}$} & $\mathrm{CK}$ & $4.10 \pm 0.04 c$ & $14.20 \pm 0.06 b$ & $35.10 \pm 2.22 c$ & $36.50 \pm 0.41 c$ \\
\hline & T1 & $7.40 \pm 0.09 b$ & $19.60 \pm 0.10 a$ & $50.70 \pm 4.19 b$ & $41.30 \pm 1.03 b$ \\
\hline & T2 & $9.30 \pm 0.14 \mathrm{a}$ & $21.10 \pm 0.27 \mathrm{a}$ & $65.50 \pm 2.43 b$ & $50.70 \pm 2.12 a$ \\
\hline & T3 & $11.50 \pm 0.33 a$ & $21.50 \pm 0.23 a$ & $95.30 \pm 5.17 \mathrm{a}$ & $53.50 \pm 1.99 a$ \\
\hline \multirow{4}{*}{$\begin{array}{l}\text { Root dry } \\
\text { weight }\left(g \text { plant }^{-1}\right)\end{array}$} & CK & $0.35 \pm 0.01 \mathrm{c}$ & $1.25 \pm 0.04 c$ & $2.30 \pm 0.11 c$ & $2.25 \pm 0.13 c$ \\
\hline & $\mathrm{T} 1$ & $1.21 \pm 0.00 b$ & $2.08 \pm 0.03 b$ & $4.37 \pm 0.07 b$ & $4.12 \pm 0.19 b$ \\
\hline & $\mathrm{T} 2$ & $1.31 \pm 0.06 \mathrm{a}$ & $2.32 \pm 0.01 b$ & $5.00 \pm 0.18 b$ & $4.27 \pm 0.07 b$ \\
\hline & T3 & $1.42 \pm 0.05 \mathrm{a}$ & $2.70 \pm 0.06 a$ & $5.72 \pm 0.27 a$ & $4.97 \pm 0.13 a$ \\
\hline
\end{tabular}

Different letters indicate significantly different values $(\mathrm{P}<0.05)$. CK: non-biochar; $\mathrm{T} 1: 15 \mathrm{~g}$ biochar per kilogram soil; T2: $30 \mathrm{~g}$ biochar per kilogram soil; T3: $45 \mathrm{~g}$ biochar per kilogram soil.

The effect of biochar on root-shoot ratio is shown in Fig. 1. The root-shoot ratio of biochar treatments was higher $(\mathrm{P}<0.05)$ than that of the non-biochar control during the whole growth stage. The ratio peaked at the tillering stage, with the T3, T2, and T1 treatments increasing the ratio by $7.16 \%, 13.97 \%$, and $4.5 \%$, respectively. However, the differences between biochar treatments and CK gradually decreased as rice growth progressed, with no significant differences during the later stages.

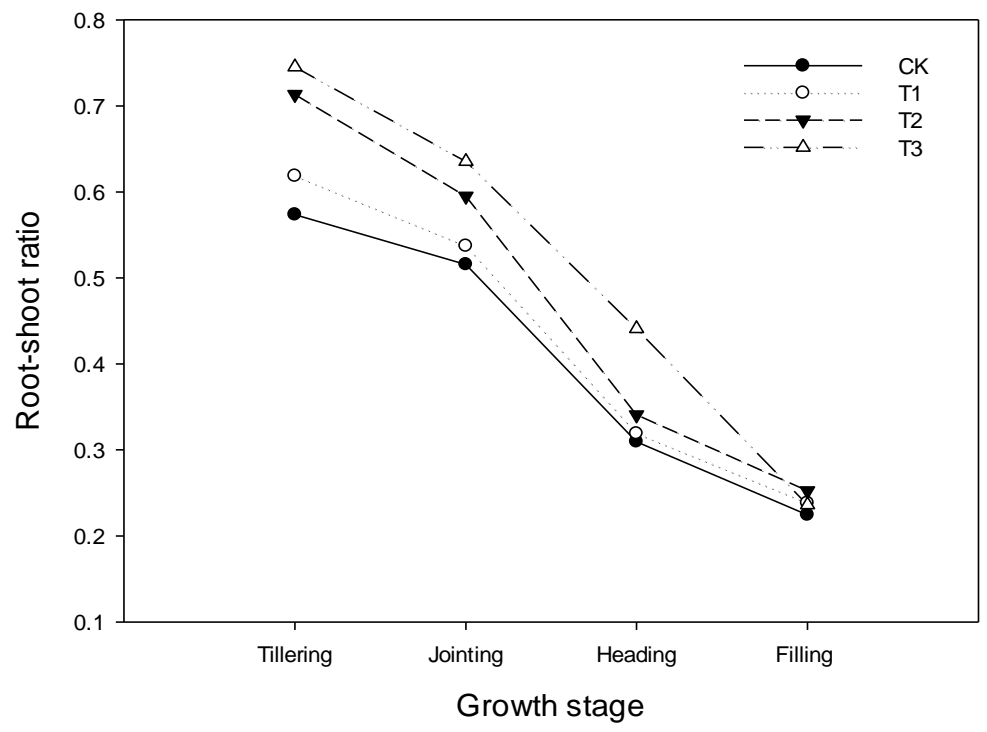

Fig. 1. Effects of biochar on the root-shoot ratio at different growth stage. CK: non-biochar; $T 1: 15$ $\mathrm{g}$ biochar per kilogram soil; T2: $30 \mathrm{~g}$ biochar per kilogram soil; T3: $45 \mathrm{~g}$ biochar per kilogram soil

\section{Root $\mathrm{Na}^{+}$and $\mathrm{K}^{+}$Accumulation Content and $\mathrm{Na}^{+} / \mathrm{K}^{+}$Ratio}

Figure 2 reveals that root $\mathrm{Na}^{+}$accumulation content increased compared to CK. However, the significant difference was only observed between T3 and non-biochar treatment. Biochar addition significantly increased $\mathrm{K}^{+}$accumulation content $(\mathrm{p}<0.05)$ and enhanced with the addition rate of biochar as compared to $\mathrm{CK}$, especially $\mathrm{T} 3$ increased by $176 \%$. Compared to non-biochar treatment, biochar application significantly lowered $\mathrm{Na}^{+}$ $/ \mathrm{K}^{+}$ratio of root in saline-sodic soil. 


\section{Root Oxidization Capacity}

The effect of biochar on root oxidization capacity of rice is shown in Fig. 3. Compared to $\mathrm{CK}$ (non-biochar), all the biochar treatments were more efficient $(\mathrm{P}<0.05)$ in enhancing the root oxidation capacity of rice (ROC) at all different growth stages. However, the performance of among biochar treatments was not consistent at different growth stages.

During the tillering stage, T1 was the highest and then decreased with the increase of biochar addition amount. At jointing and heading stages, it was shown as a trend of $\mathrm{T} 3>\mathrm{T} 2>\mathrm{T} 1>\mathrm{CK}$. But during the grain-filling stage, the highest ROC was observed for the $\mathrm{T} 2$ treatment, followed by the $\mathrm{T} 3$ and $\mathrm{T} 1$.
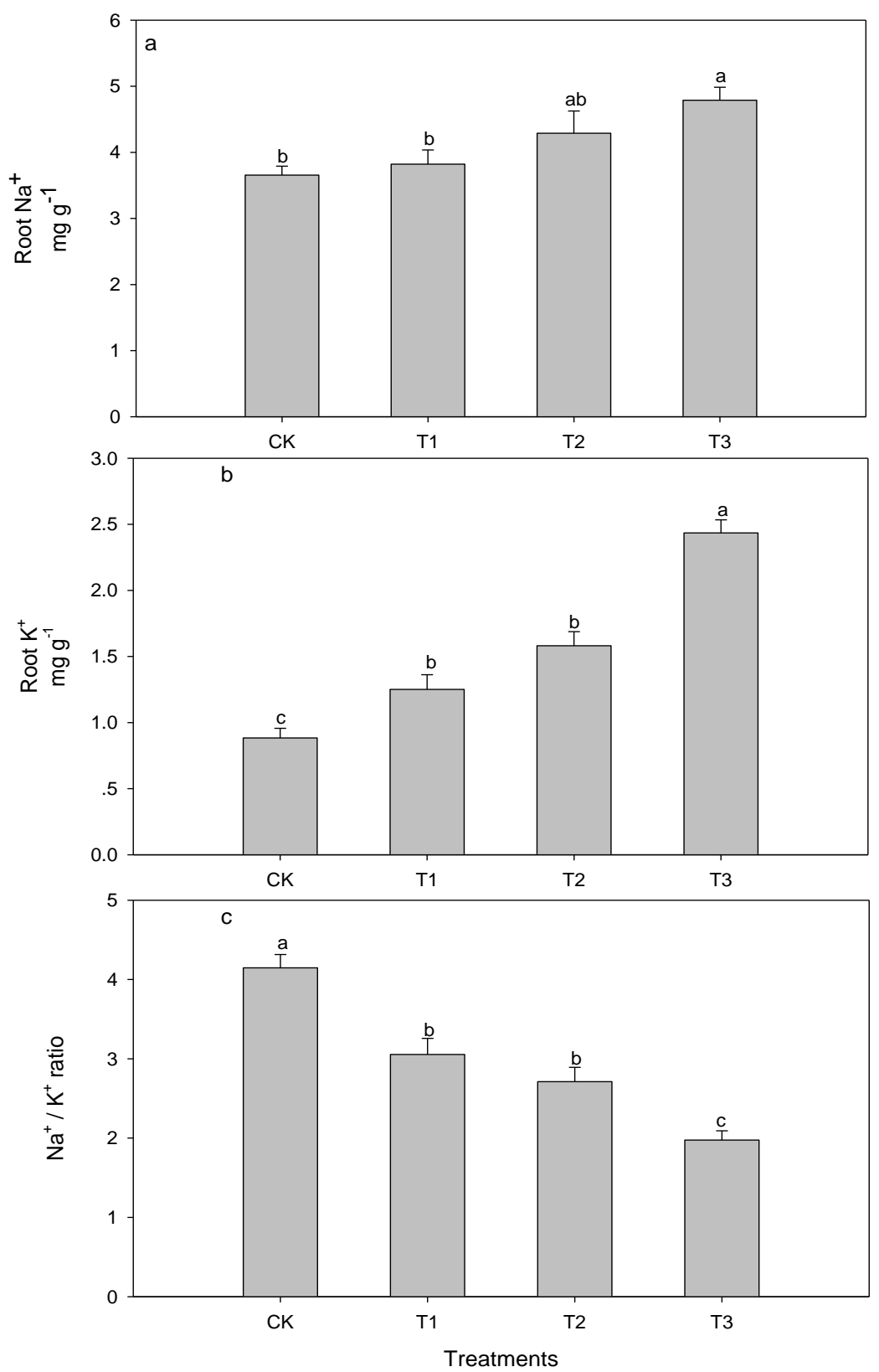

Fig. 2. Accumulation content of $\mathrm{Na}^{+}(\mathrm{a}), \mathrm{K}^{+}(\mathrm{b})$ and $\mathrm{Na}^{+} / \mathrm{K}^{+}$ratio (c) in rice root as affected by biochar treatment. CK: non-biochar; T1: $15 \mathrm{~g}$ biochar per kilogram soil; T2: $30 \mathrm{~g}$ biochar per kilogram soil; T3: $45 \mathrm{~g}$ biochar per kilogram soil 


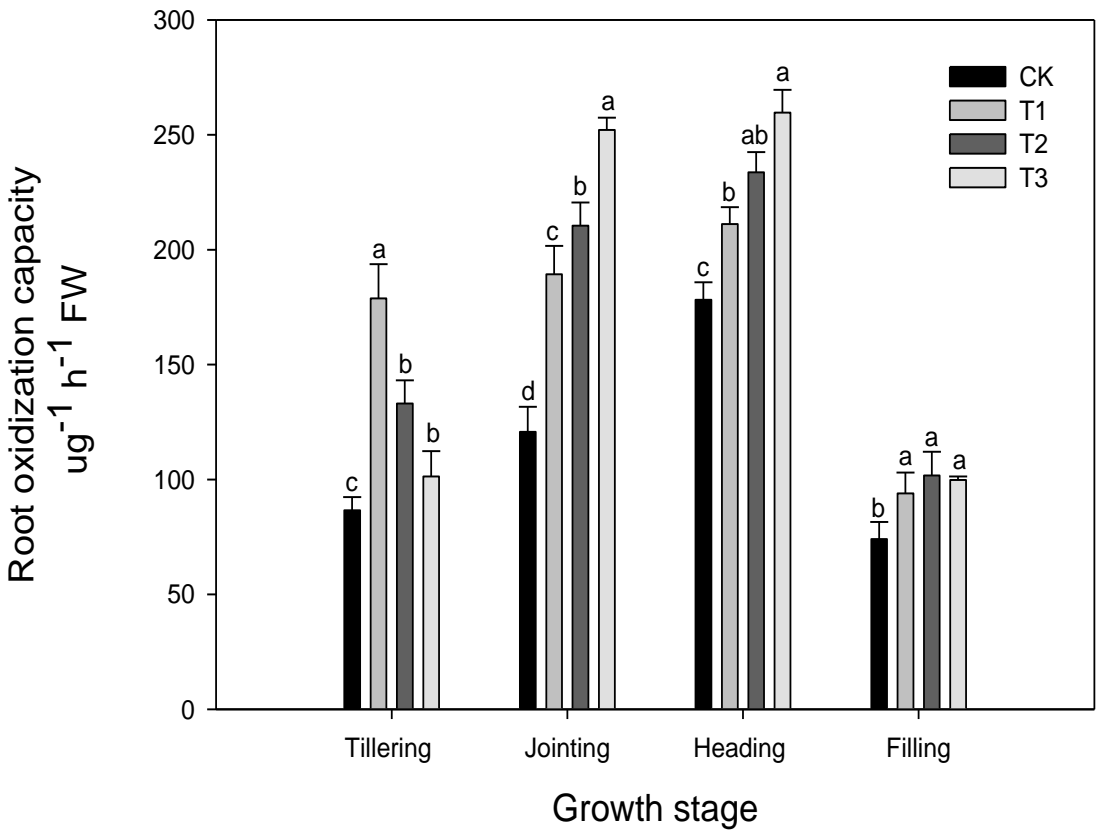

Fig. 3. Effects of biochar on root oxidation capacity $(R O C)$ at different rice growth stages. CK: non-biochar; T1: $15 \mathrm{~g}$ biochar per kilogram soil; T2: $30 \mathrm{~g}$ biochar per kilogram soil; T3: $45 \mathrm{~g}$ biochar per kilogram soil

\section{Root Total and Active Absorption Areas}

Table 4 reveals that biochar had significant effects on root total absorption areas (RTA) and root active absorption areas (RAA) of rice. RTA and RAA at whole growth stages was increased significantly as compared to CK (non-biochar), while no significant difference was found among biochar treatments. TTA was shown as T3> T2 $>\mathrm{T} 1>\mathrm{CK}$ at different stages and increasing with the rise of biochar dosage. RAA also had shown a trend of $\mathrm{T} 3>\mathrm{T} 2>\mathrm{T} 1>\mathrm{CK}$ at the tillering stage, jointing stage, and heading stage, but showed a trend of $\mathrm{T} 2>\mathrm{T} 3>\mathrm{T} 1>\mathrm{CK}$ at the filling stage.

Table 4. Effects of Biochar on the Root Total and Active Absorption Areas ( $\left.\mathrm{M}^{2}\right)$ During Different Growth Stages

\begin{tabular}{|c|c|c|c|c|}
\hline \multirow{2}{*}{ Treatment } & \multicolumn{4}{|c|}{ RTA } \\
\cline { 2 - 5 } & Tillering stage & Jointing stage & Heading stage & Filling stage \\
\hline CK & $29.21 \pm 1.19 \mathrm{~b}$ & $56.39 \pm 3.32 \mathrm{~b}$ & $84.66 \pm 2.11 \mathrm{~b}$ & $89.17 \pm 0.99 \mathrm{~b}$ \\
\hline T1 & $34.77 \pm 2.77 \mathrm{a}$ & $72.71 \pm 3.89 \mathrm{a}$ & $99.27 \pm 2.53 \mathrm{a}$ & $106.13 \pm 3.74 \mathrm{a}$ \\
\hline T2 & $37.47 \pm 1.89 \mathrm{a}$ & $74.81 \pm 2.31 \mathrm{a}$ & $101.43 \pm 1.88 \mathrm{a}$ & $110.36 \pm 4.10 \mathrm{a}$ \\
\hline T3 & $37.94 \pm 2.01 \mathrm{a}$ & $76.44 \pm 3.27 \mathrm{a}$ & $103.55 \pm 1.49 \mathrm{a}$ & $111.01 \pm 3.77 \mathrm{a}$ \\
\hline \multirow{5}{*}{ Treatment } & \multicolumn{4}{|c|}{ RAA } \\
\cline { 2 - 5 } & Tillering stage & Jointing stage & Heading stage & Filling stage \\
\hline CK & $16.46 \pm 1.39 \mathrm{~b}$ & $27.84 \pm 2.21 \mathrm{~b}$ & $35.42 \pm 2.01 \mathrm{~b}$ & $36.08 \pm 0.19 \mathrm{~b}$ \\
\hline T1 & $22.17 \pm 2.17 \mathrm{a}$ & $34.35 \pm 2.17 \mathrm{a}$ & $41.60 \pm 2.23 \mathrm{a}$ & $43.39 \pm 3.27 \mathrm{a}$ \\
\hline T2 & $23.57 \pm 1.98 \mathrm{a}$ & $35.13 \pm 2.49 \mathrm{a}$ & $43.89 \pm 1.18 \mathrm{a}$ & $47.89 \pm 2.57 \mathrm{a}$ \\
\hline T3 & $25.27 \pm 2.25 \mathrm{a}$ & $37.46 \pm 3.76 \mathrm{a}$ & $45.34 \pm 3.14 \mathrm{a}$ & $46.91 \pm 3.11 \mathrm{a}$ \\
\hline
\end{tabular}

Different letters indicate significantly different values $(P<0.05)$. RTA: root total absorption area; RAA: root active absorption area. CK: non-biochar; T1: $15 \mathrm{~g}$ biochar per kilogram soil; T2: $30 \mathrm{~g}$ biochar per kilogram soil; T3: $45 \mathrm{~g}$ biochar per kilogram soil. 


\section{Root Bleeding Rate}

Figure 4 reveals that root bleeding rate was significantly affected by biochar. The root bleeding rate with biochar treatments remarkably increased $(\mathrm{P}<0.05)$ compared with CK (non-biochar treatment) at all growth stages; however, no significantly difference was observed among biochar treatments. Root bleeding rate of biochar treatments at tilling, jointing, heading, and filling stage increased by $11.01 \%, 49.07 \%, 49.81 \%$ and $67.37 \%$, respectively, as compared to non-biochar treatment. The result showed that with the rice growth stage elongation, the difference between biochar treatments and non-biochar treatment increased gradually.

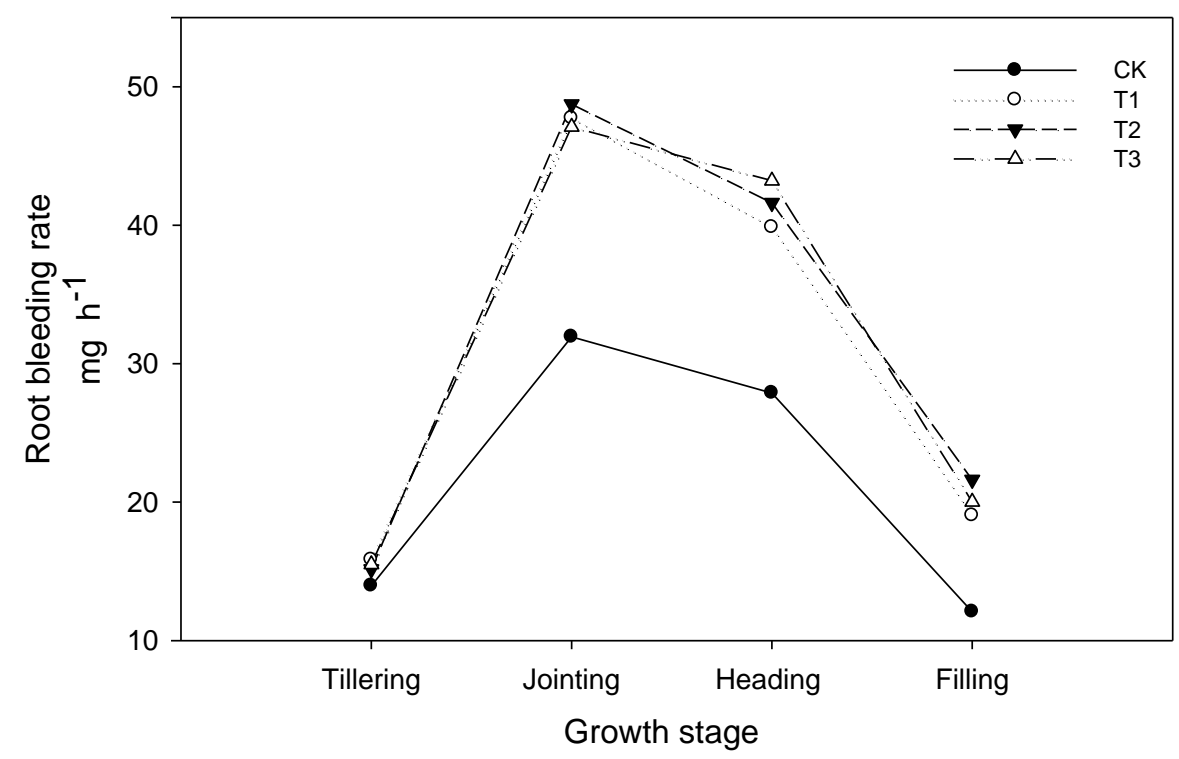

Fig. 4. Effects of biochar on root bleeding rate at different growth stages. CK: non-biochar; T1: 15 $\mathrm{g}$ biochar per kilogram soil; T2: $30 \mathrm{~g}$ biochar per kilogram soil; T3: $45 \mathrm{~g}$ biochar per kilogram soil

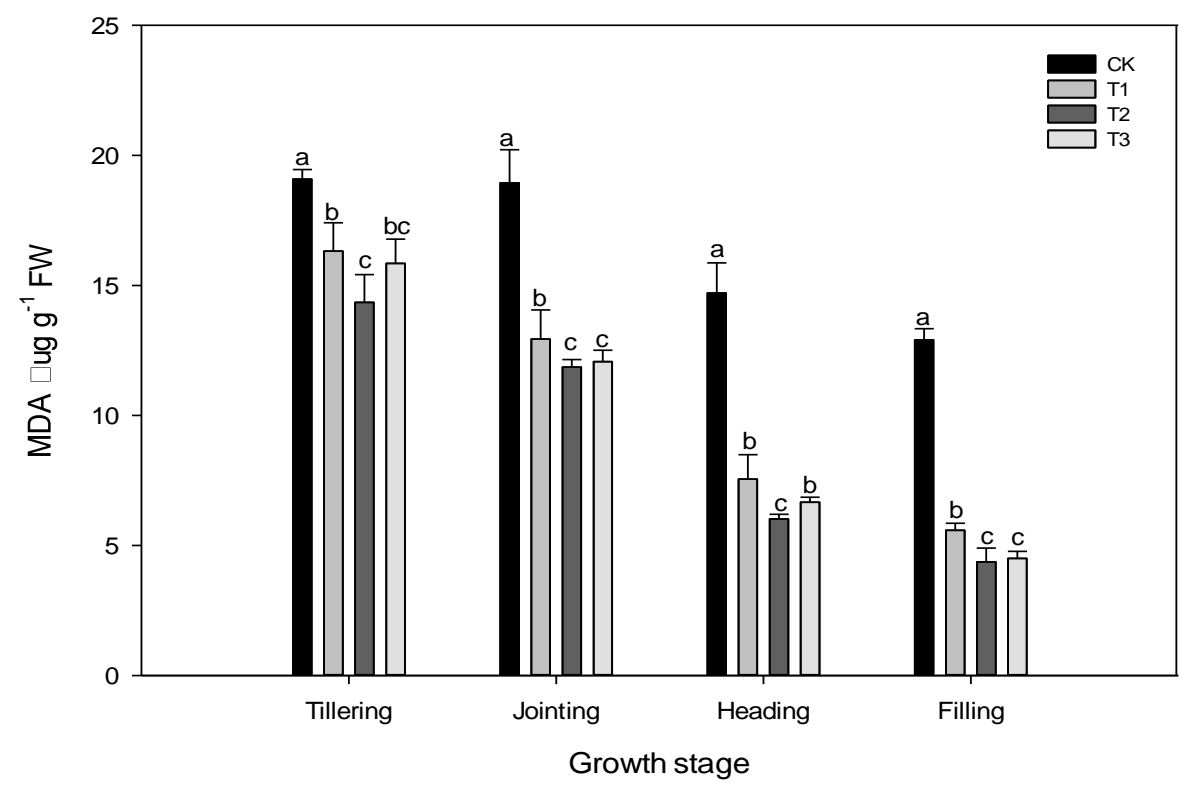

Fig. 5. Effects of biochar on root malondialdehyde content (MDA) at different rice growth stages. CK: non-biochar; T1: $15 \mathrm{~g}$ biochar per kilogram soil; T2: $30 \mathrm{~g}$ biochar per kilogram soil; T3: $45 \mathrm{~g}$ biochar per kilogram soil 


\section{Root Malondialdehyde (MDA) Content}

Saline-sodic stress can cause membrane lipid peroxidation of crop cell, and the malondialdehyde is an indicator of membrane damage by reactive oxygen species. The effect of biochar on root MDA content is shown in Fig. 5. Compared to the CK (nonbiochar), biochar addition significantly decreased MDA content $(\mathrm{p}<0.05)$ during the whole growth period. MDA was shown as $\mathrm{CK}>\mathrm{T} 1>\mathrm{T} 3>\mathrm{T} 2$ at different stages, and the significant difference was observed between T2 and CK, T1. MDA content appeared as tillering stage (TS) > jointing stage (JS) > heading stage (HS) > filling stage (FS) among different growth stages.

Table 5. Effects of Biochar on the Yield and Yield Components of Rice Plants in Saline-Sodic Paddy Soil

\begin{tabular}{|c|c|c|c|c|c|}
\hline Treatment & NPP & SP & SSR (\%) & GW(g) & YP $\left(g \cdot\right.$ hill $\left.^{-1}\right)$ \\
\hline CK & $9.21 \pm 0.11 \mathrm{c}$ & $49.08 \pm 1.21 \mathrm{a}$ & $46.07 \pm 1.03 \mathrm{c}$ & $21.82 \pm 0.12 \mathrm{a}$ & $6.11 \pm 0.19 \mathrm{c}$ \\
\hline T1 & $14.33 \pm 0.19 \mathrm{~b}$ & $50.66 \pm 1.04 \mathrm{a}$ & $67.09 \pm 0.22 \mathrm{~b}$ & $22.10 \pm 0.30 \mathrm{a}$ & $11.98 \pm 0.20 \mathrm{~b}$ \\
\hline T2 & $15.83 \pm 0.23 \mathrm{~b}$ & $52.25 \pm 2.33 \mathrm{a}$ & $72.83 \pm 0.79 \mathrm{a}$ & $23.33 \pm 0.23 \mathrm{a}$ & $13.27 \pm 0.17 \mathrm{~b}$ \\
\hline T3 & $17.20 \pm 0.17 \mathrm{a}$ & $54.04 \pm 3.17 \mathrm{a}$ & $71.26 \pm 0.64 \mathrm{a}$ & $23.48 \pm 0.31 \mathrm{a}$ & $16.60 \pm 0.32 \mathrm{a}$ \\
\hline
\end{tabular}

Different letters indicate significantly different values $(\mathrm{P}<0.05)$. CK: non-biochar; $\mathrm{T} 1: 15 \mathrm{~g}$ biochar per kilogram soil; T2: $30 \mathrm{~g}$ biochar per kilogram soil; T3: $45 \mathrm{~g}$ biochar per kilogram soil. NPP: No. of panicles per hill, SP: spikelets per panicle, SSR: seed setting rate, GW: 1000-grain weight, YP: yield per hill

\section{Yield and Yield Components}

The differences of yield and yield components of rice are shown in Table 5. All investigated yield components (NPP, SP, SSR, GW, and YP) were promoted after biochar applied. Compared to $\mathrm{CK}$, the yield and no. of panicle of biochar treatments increased significantly and showed as T3>T2>T1>CK. The difference between biochar treatments and non-biochar treatment $(\mathrm{CK})$ reached a significant level $(\mathrm{P}<0.05)$ and $\mathrm{T} 3$ was also significantly higher than $\mathrm{T} 2$ and $\mathrm{T} 1$. Compared to $\mathrm{CK}$, seed setting rate was shown as $\mathrm{T} 2>\mathrm{T} 3>\mathrm{T} 1>\mathrm{CK}$, and the difference between biochar treatment and non-biochar treatment was significant. The spikelets per panicle and 1,000-grain weight were also shown as a trend of T3>T2>T1>CK, but no significant difference between biochar treatments and CK (non-biochar) was observed.

\section{Effect of Biochar on Root Morphological Characteristics in Heavily Saline- Sodic Paddy Soil}

The restrictions of saline-alkali soil stress on crops growth are largely because of ion toxicity, osmotic imbalances, and high pH (Al-Karaki 1997). The root system is a part of the crops that directly suffered from salinity stress (Sun et al. 2019). Many studies have shown that under salinity stress, the length, root volume, root superficial area and root weight were significantly decreased and the proportion of roots with different diameters was changed, thus changing the root composition and morphological configuration (Hakim et al. 2010; Zhang et al. 2011; Van Zelm et al. 2020). These effects can severely restrict the uptake of essential nutrients and water by roots, inhibit root respiration, thus limiting the growth of aboveground plant parts and eventually leading to yield losses (Shahram et al. 2018). In this study, it was found that under saline-sodic paddy soil, root morphological characteristics such as main root length, root volumes, root dry weight (Tab. 3) and rootshoot ratio (Fig. 1) were significantly improved at all growth stages by biochar application compared with no-biochar. The underlying reason might be the biochar addition to saline- 
sodic paddy soils to a large extent counteracted saline-alkali stress by the release of essential maro and micro nutrients such as $\mathrm{Ca}, \mathrm{K}, \mathrm{N}$, and $\mathrm{P}$ in the soil, as indicated in the authors' prior study (Yao et al. 2021); simultaneously, as a highly porous material, biochar raised the total porosity, bulk density, and water holding capacity of salt-affected soils and increased the osmotic coefficient (Abrishamkesh et al. 2015; Yang 2015; Ran et al. 2019; Mehmood et al. 2020). Sun et al. (2017) found similar results on maize. The development of an enhanced root system was conducive to soil exploration, nutrient transfer, and absorption efficiency, thus contributing to yield increase (Prendergast-Miller et al. 2014; Alburquerque et al. 2015; Kamau et al. 2019; Chew et al. 2020).

\section{Effect of Biochar on the lonic Accumulation and Root Physiological Functions in Heavily Saline-Sodic Paddy Soil}

Farhangi-Abriz and Torabian (2018) found that high $\mathrm{Na}^{+}$can decrease $\mathrm{K}^{+}$content in crops under saline condition because of the exchange of $\mathrm{K}^{+}$with $\mathrm{Na}^{+}$. Na-induced $\mathrm{K}$ deduction is a proven competitive process in plant roots (Botella et al. 1997; Hafsi et al. 2007). Excessive $\mathrm{Na}^{+}$not only interferes with $\mathrm{K}$ uptake by roots but it also disrupt the metabolic processes of the root cell, causes nutritional disorders, and hinders the absorption of key nutrients, thus finally resulting in yield losses of the crops (Oster et al. 1999; Munns 2002; Ran et al. 2020). Increasing the $\mathrm{K}^{+} / \mathrm{Na}^{+}$ratio by enhancing $\mathrm{K}^{+}$availability can effectively improve the crop growth and yield in salt-affected soils (Chakraborty et al. 2016; Almeida et al. 2017; Yao et al. 2021). The authors' experiments also consistently found that under saline-sodic paddy soil, $\mathrm{K}^{+}$and $\mathrm{K}^{+} / \mathrm{Na}^{+}$ratio in rice root system was increased significantly (Fig.2), thus improving cell membrane integrity, increasing water potential, and enhancing salinity tolerance and growth of rice (Jin et al. 2018; Ran et al. 2020). Yue et al. (2016) also found that biochar application could accelerate salt leaching, lower soil EC, and provide a good environment for growth and development of plant roots.

Because plants accumulate excessive $\mathrm{Na}^{+}$and other harmful ions, the stress of saline-sodic soil can significantly increase $\mathrm{O}^{2 \cdot-}$ and $\mathrm{H}_{2} \mathrm{O}_{2}$ concentration and antioxidant activities in plant cells in salted-soils (Shahram et al. 2018). It is known that the stronger root oxidation capacity, the greater the ability of rice roots to secrete oxygen. This not only promotes root respiration and nutrients absorption, but it also helps protect the roots from toxic substances (Prendergast-Miller et al. 2014; Farhangi-Abriz and Torabian 2018; Liu et al. 2020a). In the present experiment, biochar application significantly increased the root oxidation capacity (Fig. 3) of rice at all growth stages under saline-sodic paddy soil was found. This may be because biochar is beneficial to improving rhizosphere environment (Bruun et al. 2014; Chew et al. 2020) and facilitating root growth (Tab. 3) and root cell viability (Tab. 4).

Zhang et al. (2013) demonstrated that biochar application increases rice root physiological activity, bleeding rate, and root activity in the whole growing period under sandy soils used pot experiment. Consistent with these findings, biochar application significantly increased root total absorption areas and root active absorption areas (Tab. 4), root bleeding rate (Fig. 4), and root MDA content at whole growth stages compared to nonbiochar treatment under saline-sodic paddy soil. These results indicated that biochar application can enhance the root continuous absorption ability of water and nutrients, increase the transportation efficiency of matter through the roots and retard root senescence under saline-sodic soil. The potential reasons may include the following three aspects. Firstly, biochar application offset the negative impacts of $\mathrm{Na}^{+}$and cell osmotic stress, since it could decrease the $\mathrm{Na}^{+} / \mathrm{K}^{+}$ratio (Fig. 2) and increase $\mathrm{K}^{+}$content (Fig. 2) in rice roots

Li et al. (2022). "Biochar \& rice roots in saline soil," BioResources 17(1), 1241-1256. 
(Zhang et al. 2017; Shahram et al. 2018; Mehmood et al. 2020). Secondly, biochar could improve root zone processes and activity of soil microorganisms through improving the structure of salt-affected soils (Van Zwieten et al. 2010; Kolton et al. 2016; Zhang et al. 2017). Thirdly, biochar application significantly increased root length, root volumes, root dry weight (Tab. 3), root-shoot ratio (Fig. 1), and root oxidation capacity (Fig. 3) that ultimately increased root absorption areas, root bleeding rate, and root vitality.

\section{Effect of Biochar on Grain Yield in Heavily Saline-Sodic Paddy Soil}

Biochar modifies soil physicochemical and biological parameters of salt-affected soils (Lehmann et al. 2011; Fletcher et al. 2014; Burrell et al. 2016; Futa et al. 2020), releasing essential nutrients and increasing crop yield (Thomas et al. 2013; Drake et al. 2016; Wei et al. 2020). In addition, it was found in this work that biochar could increase $\mathrm{K}$ concentration and decrease $\mathrm{Na}^{+} / \mathrm{K}^{+}$ratio of rice root system (Fig. 2) to help offset the negative impacts of saline-sodic stress. Therefore, these factors could enhance root biomass, optimize root morphology (Tab. 3 and Fig. 1) and physiological traits (Fig. 4 and Tab. 4), and increase rice yield (Zhang et al. 2013). The results of this study indicated that biochar application significantly increased grain yield (Tab. 5) by improving root morphological and root physiological functions in heavily saline-sodic paddy soil.

\section{CONCLUSIONS}

1. Biochar application had beneficial effects on root length, root volume, root dry weight, root-shoot ratio, root absorption vigor, root oxidization capacity, and root bleeding rate at all growth stages, which is of great benefit to low fertility soils such as saline-sodic paddy soils.

2. Biochar significantly decreased the root $\mathrm{Na}^{+} / \mathrm{K}^{+}$ratio and MDA content, and it increased $\mathrm{K}^{+}$concentration in rice root after biochar amendment by transient $\mathrm{Na}^{+}$ binding due to its high adsorption capacity and by releasing mineral nutrients into the soil solution.

3. The grain yield increase can be attributed to the improvement of root growth, which helped rice to take up more nutrients and water.

\section{ACKNOWLEDGEMENTS}

This study was funded by the National Natural Science Foundation of China (No. 32071951) and Jilin Province Education Department Planning Project (No. JJKH20200340KJ).

\section{REFERENCES CITED}

Abrishamkesh, S., Gorji, M., Asadi, H., Bagheri-Marand, G. H., and Pourbabaee, A. A. (2015). "Effects of rice husk biochar application on the properties of alkaline soil and lentil growth," Plant Soil Environment 11, 475-482. DOI: 10.17221/117/2015-PSE Akhtar, S. S., Andersen, M. N., and Liu, F. (2015). "Residual effects of biochar on 
improving growth, physiology and yield of wheat under salt stress," Agricultural Water Management 158, 61-68. DOI: 10.1016/j.agwat.2015.04.010

Alburquerque, J. A., Cabello, M., Avelino, R., Barrón, V., Campillo, M. C. D., and Torrent, J. (2015). "Plant growth responses to biochar amendment of mediterranean soils deficient in iron and phosphorus," Journal of Plant Nutrition and Soil Science 178, 567-575. DOI: 10.1002/jpln.201400653

Ali, S., Rizwan, M., Qayyum, M. F., Ok, Y. S., Ibrahim, M., Riaz, M., Arif, M. S., Hafeez, F., Al-Wabel, M. I., and Shahzad, A. N. (2017). "Biochar soil amendment on alleviation of drought and salt stress in plants: A critical review," Environment Science and Pollution Research 3, 1-13. DOI: 10.1007/s 11356-017-8904-X

Al-Karaki, G. N. (1997). "Barley response to salt stress at varied levels of phosphorus," Journal of Plant Nutrition 20, 1635-1643. DOI: 10.1080/01904169709365362

Almeida, D. M., Oliveira, M. M., and Saibo, N. J. M. (2017). "Regulation of $\mathrm{Na}^{+}$and $\mathrm{K}^{+}$ homeostasis in plants: Towards improved salt stress tolerance in crop plants," Genetics and Molecular Biology 40(1), 326-345. DOI: 10.1590/1678-4685-gmb2016-0106

Bastías, E. I., González-Moro. M. B., and González-Murua, C. (2004). “Zea mays L. amylacea from the Lluta Valley (Arica-Chile) tolerates salinity stress when high levels of boron are available," Plant Soil 267, 73-84. DOI: 10.1007/s 11104-005 4292-y

Botella, M. A., Martinez, V., Pardines, J., and Cerda, A. (1997). "Salinity induced potassium deficiency in maize plants," Journal of Plant Physiology 150, 200-205. DOI: 10.1016/s0176-1617(97)80203-9

Bruun, E. W., Petersen, C. T., Hansen, E., Holm, J. K., and Hauggaard-Nielsen, H. (2014). "Biochar amendment to coarse sandy subsoil improves root growth and increases water retention," Soil Use and Management 30, 109-118. DOI: 10.1111/sum.12102

Burrell, L. D., Zehetner, F., Rampazzo, N., Wimmer, B., and Soja, G. (2016). "Longterm effects of biochar on soil physical properties," Geoderma 282, 96-102. DOI: 10.1016/j.geoderma.2016.07.019

Chaganti, V. N., and Crohn, D. M. (2015). "Evaluating the relative contribution of physiochemical and biological factors in ameliorating a saline-sodic soil amended with composts and biochar and leached with reclaimed water," Geoderma 259, 45-55. DOI: 10.1016/j.geoderma.2015.05.005

Chakraborty, K., Bhaduri, D., Meena, H. N., and Kalariya, K. (2016). "External potassium $\left(\mathrm{K}^{+}\right)$application improves salinity tolerance by promoting $\mathrm{Na}^{+}$-exclusion, $\mathrm{K}^{+}$-accumulation and osmotic adjustment in contrasting peanut cultivars," Plant Physiology and Biochemistry 103, 143-153. DOI: 10.1016/j.plaphy.2016. 02.039

Chew, J. K., Zhu, L. L., Nielsen, S., Graber, E., Mitchell, D. R. G., Horvat, J., Mohammed, M., Liu, M. L., Zwieten, L. V., Donne, S., Munroe, P., Taherymoosavi, S., Pace, B., Rawal, A., Hook, J., Marjo, C., Thomas, D. S., Pan, G. X., Li, L. Q., Bian, R. J., McBeath, A. M., Bird, M., Thomas, T., Husson, O., Solaiman, Z., Joseph, S., and Fan, X. R. (2020). "Biochar-based fertilizer: Supercharging root membrane potential and biomass yield of rice," Science of the Total Environment 713, 136431. DOI: 10.1016/j.scitotenv. 2019.13643

Drake, J. A., Cavagnaro, T. R., Cunningham, S. C., Jackson, W. R., and Patti, A. F. (2016). "Does biochar improve establishment of tree seedlings in saline sodic soils?," Land Degradation \& Development 27, 52-59. DOI: 10.1002/ldr.2374 
Elgharably, A. (2011). "Wheat response to combined application of nitrogen and phosphorus in a saline sandy loam soil," Soil Science and Plant Nutrition 57, 396-402. DOI: $10.1080 / 00380768.2011 .582588$

Farhangi-Abriz, S., and Torabian, S. (2017). "Antioxidant enzyme and osmotic adjustment changes in bean seedlings as affected by biochar under salt stress," Ecotoxicology and Environmental Safety 137, 64-70. DOI: 10.1016/j.ecoenv. 2016.11.029

Farhangi-Abriz, S., and Torabian, S. (2018). "Biochar increased plant growth-promoting hormones and helped to alleviates salt stress in common bean seedlings," Journal of Plant Growth Regulation 37, 591-601. DOI: 10.1007/s 00344-017-9756-9

Fletcher, A. J., Smith, M. A., Heinemeyer, A., Lord, R., Ennis, C. J., Hodgson, E. M., and Farrar, K. (2014). "Production factors controlling the physical characteristics of biochar derived from phytoremediation willow for agricultural applications," Bioenergy Research. 7, 371-380. DOI: 10.1007/s12155-013-9380-X

Futa, B., Oleszczuk, P., Andruszczak, S., Kwiecińska-Poppe, E., and Kraska, P. (2020). "Effect of natural aging of biochar on soil enzymatic activity and physicochemical properties in long-term field experiment," Agronomy 10, 449. DOI: 10.3390/agronomy10030449

Hafsi, C., Lakhdhar, A., Rabhi, M., Debez, A., Abdelly, C., and Ouerghi, Z. (2007). "Interactive effects of salinity and potassium availability on growth, water status, and ionic composition of Hordeum maritimum," Journal of Plant Nutrition and Soil Science 170, 469-473. DOI: 10.1002/jpln.200625203

Hakim, M. A., Juraimi, A. S., Begum, M., Hanafi, M. M., Ismail, M. R., and Selamat A. (2010). "Effect of salt stress on germination and early seedling growth of rice (Oryza sativa L.)," African J. Biotechnology 9, 1911-1918. DOI: 10.5897/AJB09. 1526

Hirasawa, T., Araki, T., Matsuda, E., and Ishihara, K. (1983). "On exudation rate from the base of the leaf blade in rice plants," Japanese Journal of Crop Science 52, 574581. (in Japanese) DOI: $10.1626 /$ jcs.52.574

IUSS Working Group WRB. (2014). "World Reference Base for soil resources 2014: international soil classification system for naming soils and creating legends for soil maps," World Soil Resources Reports 106, FAO: Roma, Italy.

Jin, F., Ran, C., Anwari, Q., Geng, Y. Q., Guo, L. Y., Li, J. B., Han, D., Zhang, X. Q., Liu, X., and Shao, X. W. (2018). "Effects of biochar on sodium ion accumulation, yield and quality of rice in saline-sodic soil of the west of Songnen plain, northeast China," Plant, Soil and Environment 64, 612-618. DOI: 10.17 221/359/2018-PSE

Kamau, S., Karanja, N. K., Ayuke, F. O., and Lehmann, J.. (2019). "Short-term influence of biochar and fertilizer-biochar blends on soil nutrients, fauna and maize growth," Biology and Fertility of Soils 7(55), 661. DOI: 10.1007/s00374-019-0 1381-8

Kolton, M., Graber, E. R., Tsehansky, L., Elad, Y., and Cytryn, E. (2016). "Biocharstimulated plant performance is strongly linked to microbial diversity and metabolic potential in the rhizosphere," New Phytologist 213, 1393-1404. DOI:

10.1111/nph.14253

Lehmann, J., Rillig, M. C., Thies, J., Masiello, C. A., Hockaday, W. C., and Crowley, D. (2011). "Biochar effects on soil biota: A review," Soil Biology \& Biochemistry 43, 1812-1836. DOI: 10.1016/j.soilbio.2011.04.022

Liu, X. Y., Wang, H. D., Liu, C., Sun, B. B., Zheng, J. F., Bian, R. J., Drosos, M., Zhang, X. H., Li, L. Q., and Pan, G. X. (2020a). "Biochar increases maize yield by promoting root growth in the rainfed region," Archives of Agronomy and Soil Science, DOI: 
$10.1080 / 03650340.2020 .1796981$

Liu, D. F., Feng, Z. Y., Zhu, H. D., Yu, L. H., Yang, K. J., Yu, S., Zhang, Y. F., and Guo, W. (2020b). "Effects of corn straw biochar application on soybean growth and alkaline soil properties," BioResources 15(1), 1463-1481. DOI: 10.15376/biores. 5.1.1463-1481

Lu, R. K. (2000). Methods of Soil and Agro-chemical Analysis, China Agricultural Science and Technology Press, Beijing (in Chinese).

Mehmood, S., Ahmed, W., Ikram, M., Imtiaz, M., Mahmood, S., Tu, S. X., Chen, D. Y. (2020). "Chitosan modified biochar increases soybean (Glycine max L.) resistance to salt-stress by augmenting root morphology, antioxidant defense mechanisms and the expression of stress-responsive genes," Plants 9, 1173. DOI: 10.3390/plants9091173

Munns, R. (2002). "Comparative physiology of salt and water stress," Plant, Cell and Environment 25, 239-250. DOI: 10.1046/j.0016-8025.2001.00808.x

Munns, R., and Tester, M. (2008). "Mechanisms of salinity tolerance," Annual Review of Plant Biology 59, 651-681. DOI: 10.1146/annurev.arplant.59.032607.092911

Oster, J. D., Shainberg, I., and Abrol, I. P. (1999). "Reclamation of salt affected soils,". In: Agricultural Drainage, R.W. Skaggs and J. van Schilfgaarde (Eds.), ASA-CSSASSSA, Madison, WI, USA, pp. 659-691.

Prendergast-Miller, M. T., Duvall, M., and Sohi, S. P. (2014). "Biochar-root interactions are mediated by biochar nutrient content and impacts on soil nutrient availability," European Journal of Soil Science 65, 173-185. DOI: 10.1111/ejss.12079

Qadir, M., and Oster, J. D. (2002). "Vegetative bioremediation of calcareous sodic soils: history, mechanisms, and evaluation," Irrigation Science 21, 91-101. DOI:

10.1007/s00271-001-0055-6

Ran, C., Gulaqa, A., Zhu, J., Wang, X. W., Zhang, S. Q., Geng, Y. Q., Guo, L. Y., Jin, F., and Shao, X. W. (2020). "Benefits of biochar for improving ion contents, cell membrane permeability, leaf water status and yield of rice under saline-sodic paddy field condition," J. Plant Growth Reg. 39, 370-377. DOI: 10.1007/s 00344-019 -09988-9

Rengasamy, P. (2010). "Soil processes affecting crop production in salt-affected soils," Functional Plant Biology 37, 613-620. DOI: 10.1021/ac970256w

Shahram, T., Salar, F. A., and Judith, R. (2018). "Biochar and lignite affect $\mathrm{H}^{+}$- ATPase and $\mathrm{H}^{+}$-PPase activities in root tonoplast and nutrient contents of mung bean under salt stress," Plant Physiology and Biochemistry 129, 141-149. DOI: 10.1016/j.plaphy.2018.05.030

Stewart, R. C., and Bewley, J. D. (1980). "Lipid peroxidation associated with accelerated aging of soybean axes," Plant Physiol. 65(2), 245-248. DOI: 10.2307/4266117

Suarez, D. L. (2001). "Sodic soil reclamation: Modeling and field study," Australian Journal of Soil Research 39, 1225-1246. DOI: 10.1071/SR00094

Sun, C. X., Chen, X., Cao, M. M., Li, M. Q., and Zhang, Y. L. (2017). "Growth and metabolic responses of maize roots to straw biochar application at different rates," Plant Soil 416, 487-502. DOI: 10.1007/s11104-017-3229-6

Sun, G. F., Zhu, Y., Ye, M., Yang, J. Z., Qu, Z. Y., Mao, W., and Wu, J. W. (2019). "Development and application of long-term root zone salt balance model for predicting soil salinity in arid shallow water table area," Agricultural Water Management 213, 486-498. DOI: 10.1016/j.agwat.2018.10.043

Thomas, S. C., Frye, S., Gale, N., Garmon, M., Launchbury, R., Machado, N., Melamed, S., Murray, J., Petroff, A., and Winsborough, C. (2013). "Biochar mitigates negative effects of salt additions on two herbaceous plant species," Journal of Environmental 
Management 129, 62-68. DOI: 10.1016/j.jenvman.2013.05.057

van Zelm, E., Zhang, Y., Testerink, C. (2020). "Salt tolerance mechanisms of plants," Annual Review of Plant Biology 71, 24.1-24.31. DOI: 10.1146/annurev-arplant-0 50718-100005

Van Zwieten, L., Kimber, S., Morris, S., Chan, K. Y., Downie, A., Rust, J., Joseph, S., and Cowie, A. (2010). "Effects of biochar from slow pyrolysis of papermill waste on agronomic performance and soil fertility," Plant Soil 327, 235-246. DOI: 10.1007/s11104-009-0050-x

Wei, W. L., Zhang, S. R., Wu, L. P., Cui, D. J., and Ding, X. D. (2020). "Biochar and phosphorus fertilization improved soil quality and inorganic phosphorus fractions in saline-alkaline soils," Archives of Agronomy and Soil Science DOI: $10.1080 / 03650340.2020 .1784879$

Xiao, Q., Zhu, L. X., Zhang, H. P., Li, X. Y., Shen, Y. F., and Li, S. Q. (2016). "Soil amendment with biochar increases maize yields in a semi-arid region by improving soil quality and root growth," Crop \& Pasture Science 6(67), 495-507. DOI: $10.1071 / \mathrm{cp} 15351$

Yang, F., Li, X. Q., Xing, Y., Cheng, H. G., Zhang, L. K., He, Y. Y., and Wang, B. (2014). "Effect of biochar amendment on nitrogen leaching in saline soil," Journal of Agro-Environment Science 33, 972-977 (in chinese).

Yang, Y. L. (2015). "Effects of biochar on physical and chemical properties of the salinesodic Soil," University of Chinese Academy of Sciences, Beijing. (In Chinese)

Yao, T. X., Zhang, W. T., Gulaqa, A., Cui, Y. F., Zhou, Y. M., Weng, W. A., Wang, X., and Jin, F. (2021). "Effects of peanut shell biochar on soil nutrients, soil enzyme activity, and rice yield in heavily saline-sodic paddy field," Journal of Soil Science and Plant Nutrition 21, 655-664. DOI: 10.1007/s42729-020-00390-Z

Yue, Y., Guo, W. N., Lin, Q. M., Li, G. T., and Zhao, X. R. (2016). "Improving salt leaching in a simulated saline soil column by three biochars derived from rice straw (Oryza sativa L.), sunflower straw (Helianthus annuus), and cow manure," Journal of Soil and Water Conservation 71, 467-475. DOI: 10.2489/jswc.71.6.467

Zhang, C. S., Lin, Y., Tian, X. Y., Xu, Q., Chen, Z. H., and Lin, W. (2017). "Tobacco bacterial wilt suppression with biochar soil addition associates to improved soil physiochemical properties and increased rhizosphere bacteria abundance," Applied Soil Ecology 112, 90-96. DOI: 10.1016/j.apsoil.201 6.12.005

Zhang, J. Q., Pan, F. Y., Dou, J. H., Chen, P., Zhou, Q., and Zhou, R. Y. (2011). "Superiority of resistance in the root growth of kenaf hybrid under salt stress," Journal of China Agricultural University 16, 6-12 (in Chinese).

Zhang, W. M., Meng, J., Wang, J. Y., Fan, S. X., and Chen, W. F. (2013). "Effect of biochar on root morphological and physiological characteristics and yield in rice," Acta Agronomica Sinica 39, 1445-1451 (in Chinese).

Zhang, X. Z. (1992). Research Methods of Crop Physiology, Agriculture Press, Beijing. (in Chinese)

Zhang, X. Z., Chen, F. Y., and Wang, R. F. (1999). Plant Physiology Experimental Techniques, Liaoning Science and Technology Publishing House, Shenyang, China. (in Chinese)

Article submitted: October 21, 2021; Peer review completed: December 26, 2021; Revised version received and accepted: December 28, 2021; Published: January 5, 2022. DOI: 10.15376/biores.17.1.1241-1256 